\title{
PENGGUNAAN RUANG PADA USAHA BATIK TULIS DI KAMPUNG BATIK JETIS SIDOARJO
}

\author{
Irma Fitriyani, \\ Prof. Ir. Antariksa, MEng.,Ph.D, Dr. Lisa Dwi Wulandari, ST., MT \\ Program Magister Teknik Arsitektur Lingkungan Binaan \\ Fakultas Teknik Universitas Brawijaya, Malang \\ E-mail:irma.imani@gmail.com
}

\begin{abstract}
ABSTRAK
Kampung Batik Jetis Sidoarjo adalah lokasi penghasil batik tulis khas Sidoarjo. Di Kampung Batik Jetis terdapat 15 pengrajin batik yang bertempat tinggal sekaligus menjalankan usaha kerajinan dan penjualan di lokasi ini. Penelitian ini bertujuan untuk menganalisis dan memahami penggunaan ruang pada usaha pengrajin batik tulis di Kampung Batik Jetis Sidoarjo. Dengan metode penelitian deskriptif kualitatif dilakukan dengan pengamatan dan observasi pada ruang usaha 15 pengrajin batik tersebut sehingga didapat hasil identifikasi yang akan dianalisa dengan mengacu pada teori yang terkait. Skala penelitian ini adalah hanya melingkupi ruang secara mikro. Hasil yang didapatkan dari penelitian ini adalah tentang penggunaan ruang untuk usaha pengrajin batik tulis di Kampung Batik Jetis ini secara umum menunjukkan bahwa setiap pengrajin melakukan aktivitas usaha dalam ruang usaha mereka masing-masing yang dimiliki sendiri (13 pengrajin) atau dipinjam dari pengrajin lain (2 pengrajin). Ruang yang digunakan terdiri dari ruang untuk proses produksi dan pasca produksi. Terdapat beberapa tipe ruang usaha berdasarkan ruang yang dimiliki/ digunakan. Sifat penggunaan ruang adalah permanen dan terdapat tipe ruang usaha berdasarkan letak/ proporsinya yang merupakan kombinasi dari tipe berimbang, campuran dan terpisah.
\end{abstract}

Kata kunci: penggunaan ruang, aktivitas usaha batik, pengrajin batik tulis

\section{Pendahuluan}

Batik adalah salah satu hasil kerajinan, keterampilan dan seni dalam hal membuat bahan pakaian yang merupakan warisan seni budaya nenek moyang Indonesia yang telah diakui dunia. Batik tulis merupakan salah satu jenis batik yang teknik pembuatannya menggunakan tangan yaitu untuk menuliskan/ melukiskan lilin/ malam pada kain dengan menggunakan alat membatik yaitu canting. Lilin yang telah menempel di kain akan mencegah penyerapan warna ketika kain dicelup pewarnaan, sehingga akan menghasilkan kain batik dengan corak dan warna khas yang diinginkan.

Keterampilan membatik merupakan tradisi yang didapatkan secara turun temurun dari generasi sebelumnya dan tidak hanya sebagai hasil kerajinan semata, namun juga sebagai kegiatan usaha ekonomi yang menjadi sumber penghasilan bagi pengrajinnya

Di Indonesia terdapat berbagai macam jenis batik berdasarkan daerah yang menghasilkannya dengan corak, warna dan tema lokal yang bervariasi dan memiliki ciri khasnya masing-masing. Salah satu batik khas daerah yang dikenal adalah batik tulis 
khas Sidoarjo dan salah satu lokasi penghasilnya adalah Kampung Batik Jetis di Sidoarjo. Di Kampung Jetis ini terdapat banyak pengrajin yang menghasilkan batik sekaligus bertempat tinggal di kampung ini pula, sehingga terdapat rumah pengrajin batik yang selain berfungsi sebagai hunian juga berfungsi sebagai tempat usaha batik. Rumah yang demikian sehingga fungsi hunian harus berbagi dengan fungsi usaha disebut rumah produktif (Maninggar, 2010). Kegiatan usaha ekonomi yang dilakukan di rumah merupakan ciri pokok dari UBR (Usaha Berbasis Rumah Tangga), usaha batik merupakan salah satu jenis UBR tipe manufacture/ memproduksi barang (Silas, 2000). Aktivitas usaha batik di Kampung Jetis ini selain aktivitas memproduksi batik juga terdapat aktivitas penjualan dari batik yang yang dihasilkan.

Berbagai aktivitas manusia termasuk aktivitas usaha membutuhkan ruang sebagai wadahnya. Aktivitas manusia dapat pula menciptakan suatu ruang untuk memenuhi kebutuhan aktivitas itu sendiri. Dapat dipahami bahwa bahwa dalam kajian arsitektur tentang suatu ruang akan selalu terkait dengan aktivitas manusia dan manusia sebagai pelaku aktivitas tersebut.

Penelitian ini dianggap menarik untuk dilakukan karena keunikan yang dimiliki oleh Kampung Batik Jetis, yaitu latar belakang kampung Jetis yang dikenal sejak jaman dahulu sebagai daerah penghasil batik dan banyaknya pengrajin/ saudagar batik disana. Usaha batik pengrajin sebagai UBR yang menjalankan usaha sekaligus bertempat tinggal di kampung ini tentunya membutuhkan ruang untuk kegiatannya masing-masing padahal semua kegiatan umumnya berada pada lingkup rumah tinggal para pengrajin. Adanya dua kegiatan/ aktivitas yaitu aktivitas rumah tangga dan aktivitas usaha dalam satu lingkup rumah/ tempat tinggal menimbulkan hal yang menarik untuk diteliti tentang bagaimana penggunaan ruangnya terutama ruang untuk kebutuhan usaha terlebih apabila dikaitkan dengan jenis UBR itu sendiri yaitu jenis usaha produksi batik yang tentunya memiliki kebutuhan ruang yang aak berbeda dibandingkan jenis UBR lainnya.

Dengan latar belakang tersebut maka penelitian ini bertujuan untuk mengidentifikasi dan menganalis bagaimana penggunaan ruang untuk UBR yaitu usaha batik di Kampung Batik Jetis ini. Dari penelitian ini diharapkan akan diketahui tentang pemanfaatan ruang yaitu ruang apa saja yang digunakan terkait dengan aktivitas usaha batik, tipe ruang usaha berdasar letak dan proporsinya, serta hubungan antar ruang/ organisasi ruang pada ruang usaha yang digunakan.

\section{Metode Penelitian}

Metode penelitian yang digunakan adalah metode penelitian deskriptif kualitatif yaitu metode penelitian dengan mengumpulkan data-data sesuai keadaan yang sebenarnya terkait dengan deskripsi atas kejadian, peristiwa dan fenomena yang terjadi di lokasi studi yang kemudian dianalis untuk mendapatkan gambaran dan kesimpulan yang dapat menjawab permasalahan dan mencapai tujuan penelitian.

Penelitian deskriptif kualitatif dilakukan dengan observasi secara langsung ke obyek penelitian yaitu ruang usaha pengrajin batik tulis dan wawancara kepada responden sebagai pelaku aktivitas usaha yaitu pada pengrajin batik tulis tersebut sehingga didapatkan data-data secara arsitektural maupun non arsitektural yang terkait dengan aktivitas usaha batik.

Dengan pendekatan deskriptif maka akan didapatkan gambaran tentang bagaimana penggunaan ruang usaha pengrajin batik tulis di Kampung Batik Jetis, yang diawali dengan mengidentifikasikan aktivitas apa yang dilakukan serta ruang apa saja yang 
digunakan dalam usaha batik tulis. Selanjutnya hasil identifikasi tersebut akan dianalisa tentang bagaimana penggunaan ruang untuk usaha dengan mengacu pada teori yang terkait sehingga didapatkan kesimpulan akhir.

Obyek penelitian ini adalah ruang usaha para pengrajin batik tulis yang berlokasi di Kampung Batik Jetis Sidoarjo, yaitu di kelurahan Lemah Putro, Kecamatan Sidoarjo, Kabupaten Sidoarjo. Dari pengumpulan data didapatkan sejumlah 15 pengrajin batik tulis yang menjalankan usaha batik tulisnya sekaligus bertempat tinggal di kampung ini. Skala penelitian ini adalah hanya melingkupi ruang mikro yaitu melihat bagaimana ruang usaha dan menganalisis terkait dengan penggunaan ruangnya secara mikro.

\section{Hasil Dan Pembahasan}

\subsection{Pengrajin batik tulis di Kampung Batik Jetis Sidoarjo}

Kampung Batik Jetis ini telah diresmikan oleh Bupati Sidoarjo sejak tahun 2008 dan merupakan lokasi penghasil batik tulis khas Sidoarjo yang telah dikenal masyarakat. Konon Kampung Jetis ini telah dikenal sebagai penghasil batik tulis tradisional sejak tahun 1675 dan pada masa dulunya di kampung ini banyak terdapat juragan-juragan pengrajin batik tulis yang memiliki usaha batik tulis dengan sejumlah pekerja (buruh batik) masing-masing. Seiring dengan berjalannya waktu usaha batik pun mengalami pasang surut hingga akhirnya sebagian dapat bertahan sebagaimana yang dikenal sebagai Kampung Batik Jetis saat ini. Sebagian dari pengrajin batik tulis yang ada saat ini merupakan generasi ke sekian dari para pengrajin maupun pekerja batik di masa dulu.

Di lokasi penelitian Kampung Batik Jetis ini terdapat 15 pengrajin batik tulis dan sebagian diantaranya memiliki hubungan kekerabatan (Tabel 1 dan Gambar 1)

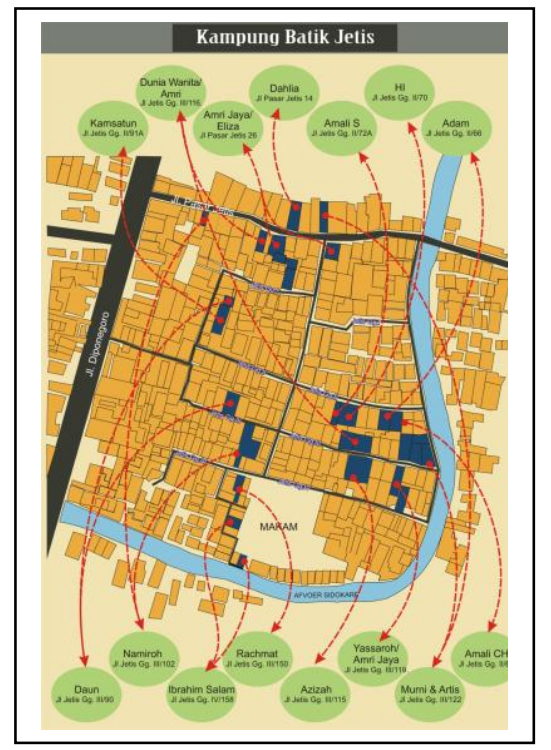

Gambar 1. Lokasi pengrajin batik tulis di Kampung Batik Jetis.

Tabel 1. Hubungan kekerabatan pengrajin batik tulis di Kampung Batik Jetis

\begin{tabular}{|l|l|l|}
\hline \multicolumn{1}{|c|}{ No } & \multicolumn{1}{|c|}{ Pengrajin batik tulis } & \multicolumn{1}{c|}{ Hubungan kekerabatan pemilik usaha batik } \\
\hline 1. & Batik Tulis Amri & Ibu dari Yassaroh, Azizah, Amri Jaya \\
\hline 2. & Batik Tulis Yassaroh & Anak dari Amri \\
\hline 3. & Batik Tulis Azizah & Anak dari Amri \\
\hline 4. & Batik Tulis Amri Jaya & Anak dari Amri \\
\hline 5. & Batik Tulis Rachmat & Kakak dari Amali CH, Amali S \\
\hline
\end{tabular}




\begin{tabular}{|l|l|l|}
\hline 6. & Batik Tulis Amali CH & Adik dari Rachmat \\
\hline 7. & Batik Tulis Amali S & Adik dari Rachmat \\
\hline 8. & Batik Tulis HI & Paman dari Adam dan Murni \& Artis \\
\hline 9. & Batik Tulis Adam & Keponakan dari HI \\
\hline 10. & Batik Tulis Murni dan Artis & Keponakan dari HI \\
\hline 11. & Batik Tulis Namiroh & Tidak ada hubungan \\
\hline 12. & Batik Tulis Daun & Tidak ada hubungan \\
\hline 13. & Batik Tulis Ibrahim Salam & Tidak ada hubungan \\
\hline 14. & Batik Tulis Kamsatun & Tidak ada hubungan \\
\hline 15. & Batik Tulis Dahlia & Tidak ada hubungan \\
\hline
\end{tabular}

Dari keseluruhan pengrajin batik tulis tersebut terdapat tiga kelompok pengrajin yang memiliki hubungan kekerabatan diantaranya sedangkan selebihnya tidak terdapat hubungan kekerabatan. Hal ini dimungkinkan karena keterampilan membatik didapatkan secara turun temurun yang diwariskan oleh generasi sebelumnya (orang tua, nenek/ kakek pengrajin) sehingga wajar apabila kemudian beberapa diantara pengrajin masih saling bersaudara atau terdapat hubungan keluarga yang kebetulan memiliki minat yang sama sebagai pengrajin batik.

Dari adanya hubungan kekerabatan tersebut hanya sebagian kecil yang mempengaruhi penggunaan ruang untuk usaha batik tulis, yaitu pengrajin Batik Yassaroh yang meminjam ruang untuk produksi (workshop) milik Batik Amri Jaya dan Batik Amali S yang meminjam workshop milik Amali CH. Ini berarti menunjukkan bahwa setiap pengrajin melakukan proses usaha batiknya secara sendiri-sendiri, tidak ada proses yang dilakukan secara bekerja sama sehingga ruang usaha yang digunakan cenderung merupakan ruang usaha mereka masing-masing kecuali adanya penggunaan ruang untuk sebagian proses produksi batik pada dua pengrajin yang masih meminjam ruang workshop basah milik saudaranya tersebut, meski demikian proses produksi tetap dikerjakan oleh pengrajin/ pekerja masing-masing.

\subsection{Aktivitas usaha batik tulis yang dilakukan dan ruang yang digunakan}

Aktivitas/ kegiatan yang dilakukan pengrajin/ pekerja dalam rangka usaha batik tulisnya pada umumnya meliputi persiapan kain mori hingga penjualan batik dengan menggunakan ruangnya masing-masing.

Aktivitas usaha batik tulis yang dilakukan pengrajin secara umum terdiri dari aktivitas produksi dan pasca produksi sebagai berikut:

1. Aktivitas produksi

- Persiapan kain mori (memotong, mengkethel, membuat pola)

- Pembatikan (melukiskan lilin dengan canting sesuai pola, meliputi mereng-reng, menutup, menembok)

- Pewarnaan kering (menyolet, yaitu mencoletkan bahan warna tertentu pada bagian kain sesuai desain/ pola yang dinginkan)

- Pewarnaan basah (mencelupkan kain ke larutan bahan warna)

- Pengeringan dengan dianginkan dan dijemur

- Penyimpanan bahan (kain mori, batik setengah jadi, bahan warna)

- Finishing (pelipatan, pelabelan, pengemplongan)

2. Aktivitas pasca produksi

- Penyimpanan batik jadi, display batik

- Penjualan batik dengan showroom, tanpa showroom, dengan toko. 
Setiap aktivitas usaha batik dilakukan oleh pengrajin sendiri dengan dibantu oleh anggota keluarganya (isteri, anak), dan ada pula pengrajin yang mengerjakan usaha batik ini dengan dibantu oleh para pekerja. Temuan yang menarik adalah para pekerja batik yang bekerja membantu pengrajin di Kampung Jetis ini justru sebagian besar berasal dari luar wilayah Kampung Jetis. Mereka tinggal di daerah lain dalam wilayah Sidoarjo bahkan ada pula yang berasal dari Tulungagung. Para pekerja tersebut datang bekerja ke Kampung Batik Jetis sesuai waktu kerja yang telah ditentukan, misalnya setiap hari kerja mulai Senin hingga Sabtu dari pagi hingga sore secara rutin, namun ada pula pekerja yang bekerja secara periodik setiap beberapa hari sekali atau tergantung kebutuhan dari pengrajin yang memperkerjakan mereka. Biasanya hal ini terjadi pada pengrajin yang skala produksinya tidak terlalu besar dan jumlah batik yang dikerjakan tidak terlalu banyak sehingga proses produksi batik akan lebih efektif dan ekonomis apabila dikerjakan setelah kain terakumulasi dalam jumlah tertentu.

Temuan lainnya pada pengrajin batik di Kampung Jetis ini adalah adalah bahwa ada salah satu proses produksi batik, yaitu proses mereng-reng yang ternyata tidak dilakukan di ruang usaha batik di wilayah Kampung Jetis, namun ternyata dilakukan oleh para pekerja batik di rumahnya masing-masing, yang sebagian besar mereka tinggal di daerah Tulangan, Tenggulunan dan Tulungagung. Secara berkala, yaitu beberapa hari sekali hingga setiap 1-2 minggu sekali pekerja mengembalikan kain yang sudah selesai direng-reng sekaligus mengambil sejumlah kain mori yang ;ain yang juga siap untuk direng-reng. Pekerja reng-reng lebih memilih bekerja di rumahnya masingmasing karena dianggap waktu kerjanya yang lebih efektif, mereka dapat bekerja dengan waktu yang lebih bebas sambil tetap dapat mengurus rumah tangganya, sedangkan para pengrajin batik di Kampung Jetis memilih menggunakan pekerja di daerah tersebut karena telah cocok dengan hasil pekerjaan mereka, bahkan di masa dulunya banyak para pekerja reng-reng yang bekerja dan tinggal di rumah majikannya di Kampung Jetis, namun setelah berkeluarga mereka lebih memilih bekerja di rumahnya masing-masing.

Dari rangkaian aktivitas usaha batik yang dilakukan pengrajin dengan dibantu oleh pekerjanya tersebut ditemukan bahwa meski sebagian besar proses di lakukan di dalam Kampung Jetis, namun ada beberapa proses yang dilakukan di luar dan ada pula beberapa pengrajin yang tidak melakukan aktivitas usaha batik secara lengkap sehingga didapatkan beberapa kategori pengrajin berdasarkan aktivitas dan ruang usaha yang digunakan sebagaimana ditunjukkan dalam Tabel 2 dan Tabel 3.

Tabel 2. Proses produksi yang dilakukan dan ruang yang digunakan oleh pengrajin.

\begin{tabular}{|l|l|l|l|}
\hline $\begin{array}{c}\text { Perusahaan Pengrajin } \\
\text { Batik Tulis }\end{array}$ & Proses Produksi & $\begin{array}{l}\text { Ruang untuk } \\
\text { proses produksi }\end{array}$ & $\begin{array}{l}\text { Status ruang proses } \\
\text { produksi }\end{array}$ \\
\hline 1. Batik Amri & $\begin{array}{l}\text { lengkap (tanpa } \\
\text { reng-reng }\end{array}$ & $\begin{array}{l}\text { Workshop di } \\
\text { rumah }\end{array}$ & Milik sendiri \\
\hline 2. Batik Yassaroh & $\begin{array}{l}\text { lengkap (tanpa } \\
\text { reng }\end{array}$ & $\begin{array}{l}\text { Workshop di } \\
\text { samping rumah }\end{array}$ & $\begin{array}{l}\text { Meminjam } \\
\text { workshop Amri Jaya }\end{array}$ \\
\hline 3. Batik Azizah & $\begin{array}{l}\text { lengkap (tanpa } \\
\text { reng }\end{array}$ & $\begin{array}{l}\text { Workshop di } \\
\text { rumah }\end{array}$ & Milik sendiri \\
\hline 4. Batik Amri Jaya & $\begin{array}{l}\text { lengkap (tanpa } \\
\text { reng }\end{array}$ & $\begin{array}{l}\text { Workshop di } \\
\text { rumah dan di }\end{array}$ & Milik sendiri \\
\hline
\end{tabular}




\begin{tabular}{|c|c|c|c|}
\hline $\begin{array}{c}\text { Perusahaan Pengrajin } \\
\text { Batik Tulis }\end{array}$ & Proses Produksi & $\begin{array}{c}\text { Ruang untuk } \\
\text { proses produksi }\end{array}$ & $\begin{array}{c}\text { Status ruang proses } \\
\text { produksi }\end{array}$ \\
\hline & & tempat terpisah & \\
\hline 5. Batik Rahmat & $\begin{array}{l}\text { lengkap (tanpa } \\
\text { reng }\end{array}$ & $\begin{array}{l}\text { Workshop di } \\
\text { rumah }\end{array}$ & Milik sendiri \\
\hline 6. Batik Amali $\mathrm{CH}$ & $\begin{array}{l}\text { lengkap (tanpa } \\
\text { reng }\end{array}$ & $\begin{array}{l}\text { Workshop di } \\
\text { rumah }\end{array}$ & Milik sendiri \\
\hline 7. Batik Amali S & $\begin{array}{l}\text { lengkap (tanpa } \\
\text { reng }\end{array}$ & $\begin{array}{l}\text { Workshop di } \\
\text { rumah saudara }\end{array}$ & Milik Amali CH \\
\hline 8. Batik HI & $\begin{array}{l}\text { lengkap (tanpa } \\
\text { reng }\end{array}$ & workshop & Milik sendiri \\
\hline 9. Batik Adam & $\begin{array}{l}\text { lengkap (tanpa } \\
\text { reng }\end{array}$ & workshop & Milik sendiri \\
\hline $\begin{array}{l}\text { 10. Batik Murni dan } \\
\text { Artis }\end{array}$ & $\begin{array}{l}\text { lengkap (tanpa } \\
\text { reng }\end{array}$ & workshop & Milik sendiri \\
\hline 11. Batik Namiroh & $\begin{array}{l}\text { lengkap (tanpa } \\
\text { reng }\end{array}$ & workshop & Milik sendiri \\
\hline 12. Batik Daun & $\begin{array}{l}\text { lengkap (tanpa } \\
\text { reng }\end{array}$ & $\begin{array}{l}\text { Workshop di } \\
\text { tempat terpisah }\end{array}$ & Milik sendiri \\
\hline 13. Batik Ibrahim Salam & $\begin{array}{l}\text { lengkap (tanpa } \\
\text { reng, nembok, } \\
\text { nutup) }\end{array}$ & $\begin{array}{l}\text { Workshop di } \\
\text { tempat terpisah }\end{array}$ & Milik sendiri \\
\hline 14. Batik Kamsatun & $\begin{array}{l}\text { lengkap (tanpa } \\
\text { reng }\end{array}$ & workshop & Milik sendiri \\
\hline 15. Batik Dahlia & $\begin{array}{l}\text { lengkap (tanpa } \\
\text { reng }\end{array}$ & workshop & Milik sendiri \\
\hline
\end{tabular}

Tabel 3. Proses pasca produksi yang dilakukan ruang yang digunakan dan kategori tipe ruang usaha.

\begin{tabular}{|l|c|c|c|}
\hline $\begin{array}{c}\text { Perusahaan Pengrajin } \\
\text { Batik Tulis }\end{array}$ & $\begin{array}{c}\text { Pasca produksi: } \\
\text { penyimpanan, } \\
\text { display, } \\
\text { penjualan }\end{array}$ & $\begin{array}{c}\text { Ruang yang } \\
\text { digunakan } \\
\text { untuk pasca } \\
\text { produksi }\end{array}$ & $\begin{array}{c}\text { Kategori tipe Ruang } \\
\text { usaha }\end{array}$ \\
\hline 1. Batik Amri & lengkap & $\begin{array}{c}\text { Show room di } \\
\text { rumah dan toko } \\
\text { terpisah }\end{array}$ & 2 \\
\hline 2. Batik Yassaroh & $\begin{array}{c}\text { Tanpa } \\
\text { penyimpanan, } \\
\text { display }\end{array}$ & - & 5 \\
\hline 3. Batik Azizah & lengkap & $\begin{array}{c}\text { Show room di } \\
\text { rumah }\end{array}$ & 1 \\
\hline 4. Batik Amri Jaya & lengkap & $\begin{array}{c}\text { Show room di } \\
\text { rumah dan toko } \\
\text { terpisah }\end{array}$ & 2 \\
\hline 5. Batik Rahmat & lengkap & $\begin{array}{c}\text { Show room di } \\
\text { rumah }\end{array}$ & 1 \\
\hline 6. Batik Amali CH & lengkap & $\begin{array}{c}\text { Show room di } \\
\text { rumah }\end{array}$ & 1 \\
\hline
\end{tabular}




\begin{tabular}{|l|c|c|c|}
\hline $\begin{array}{c}\text { Perusahaan Pengrajin } \\
\text { Batik Tulis }\end{array}$ & $\begin{array}{c}\text { Pasca produksi: } \\
\text { penyimpanan, } \\
\text { display, } \\
\text { penjualan }\end{array}$ & $\begin{array}{c}\text { Ruang yang } \\
\text { digunakan } \\
\text { untuk pasca } \\
\text { produksi }\end{array}$ & $\begin{array}{c}\text { Kategori tipe Ruang } \\
\text { usaha }\end{array}$ \\
\hline 7. Batik Amali S & lengkap & $\begin{array}{c}\text { Show room di } \\
\text { rumah }\end{array}$ & 4 \\
\hline 8. Batik HI & lengkap & $\begin{array}{c}\text { Show room di } \\
\text { rumah }\end{array}$ & 1 \\
\hline 9. Batik Adam & lengkap & $\begin{array}{c}\text { Show room di } \\
\text { rumah }\end{array}$ & 2 \\
\hline $\begin{array}{l}\text { 10. Batik Murni dan } \\
\text { Artis }\end{array}$ & $\begin{array}{c}\text { Show room di } \\
\text { rumah dan toko } \\
\text { terpisah }\end{array}$ & 2 \\
\hline $\begin{array}{l}\text { 11. Batik Namiroh } \\
\text { l2. Batik Daun }\end{array}$ & $\begin{array}{c}\text { Show room di } \\
\text { rumah dan toko } \\
\text { terpisah }\end{array}$ & 7 \\
\hline 13. Batik Ibrahim Salam & Tanpa display & $\begin{array}{c}\text { Penyimpanan } \\
\text { sementara di } \\
\text { rumah }\end{array}$ & 6 \\
\hline 14. Batik Kamsatun & lengkap & $\begin{array}{c}\text { Show room di } \\
\text { rumah }\end{array}$ & 2 \\
\hline 15. Batik Dahlia & lengkap & $\begin{array}{c}\text { Show room di } \\
\text { rumah } \\
\text { sekaligus toko }\end{array}$ & 2 \\
\hline
\end{tabular}

Dari Tabel 2 dan Tabel 3 maka dapat dikategorikan penggunaan ruang usaha pengrajin batik berdasarkan ruang yang dimiliki dan digunakan sebagai berikut:

- Tipe 1: Workshop dan ruang display berada di rumah (6 pengrajin)

- Tipe 2: Workshop dan ruang display berada di rumah, memiliki toko terpisah (4 pengrajin)

- Tipe 3: Workshop dan ruang display berada di rumah sekaligus toko (1 pengrajin)

- Tipe 4: Workshop meminjam milik pengrajin lain, ruang display di rumah (1 pengrajin)

- Tipe 5: Workshop meminjam milik pengrajin lain, tanpa ruang display (1 pengrajin)

- Tipe 6: Workshop di tempat terpisah tanpa ruang display (1 pengrajin)

- Tipe 7: Workshop di tempat terpisah, ruang display di rumah (1 pengrajin)

Secara umum ruang yang digunakan untuk aktivitas usaha setiap pengrajin batik di kampung ini adalah ruang untuk proses produksi dan ruang untuk pasca produksi. Ruang untuk proses produksi terdiri dari workshop kering, workshop basah, ruang pengeringan, ruang penjemuran, ruang campuran. Sedangkan ruang untuk proses pasca produksi terdiri dari ruang display/ showroom atau ruang campuran). Ruang yang digunakan untuk aktivitas usaha pada setiap pengrajin tergantung pada ruang usaha yang dimiliki atau dapat digunakan oleh pengrajin tersebut dan aktivitas usaha batik yang dilakukan oleh pengrajin tersebut, karena tidak semua pengrajin melakukan seluruh proses atau aktivitas usaha secara lengkap (Tabel 2 dan Tabel 3). Ruang yang 
digunakan untuk setiap aktivitas usaha dan waktu penggunaannya ditunjukkan dalam Tabel 4.

Waktu penggunaan ruang untuk produksi yang dilakukan pengrajin/pekerja adalah setiap hari kerja dan jam kerja pagi hingga sore. Proses pasca produksi dilakukan secara periodik, tidak pasti setiap hari dan cenderung bebas karena kegiatan ini akan dilakukan setelah proses produksi selesai dilakukan dan kain batik jadi telah siap diproses yang waktunya tidak dapat ditentukan (sewaktu-waktu). Beberapa pengrajin yang mengerjakan sendiri usahanya tanpa dibantu oleh pekerja maka waktu kerja dan waktu penggunaan ruang cenderung lebih bebas, tidak terikat jam kerja. Beberapa pengrajin yang memiliki skala produksi tidak terlalu besar, waktu kerjanya cenderung periodik karena batik yang dikerjakan tidak terlalu banyak dan proses produksi batik dikerjakan setelah kain terakumulasi dalam jumlah tertentu.

Tabel 4. Aktivitas usaha pengrajin, ruang yang digunakan dan waktu penggunaan ruang

\begin{tabular}{|c|c|c|c|}
\hline & Aktivitas usaha & $\begin{array}{l}\text { Ruang yang } \\
\text { digunakan }\end{array}$ & Waktu penggunaan ruang \\
\hline 1. & $\begin{array}{l}\text { Persiapan kain } \\
\text { mori }\end{array}$ & $\begin{array}{l}\text { Ruang campuran } \\
\text { depan, ruang } \\
\text { persiapan. }\end{array}$ & $\begin{array}{l}\text { Periodik (beberapa hari sekali), } \\
\text { relatif tidak terlalu lama (tidak } \\
\text { sepanjang hari) }\end{array}$ \\
\hline 2. & $\begin{array}{l}\text { Pembatikan } \\
\text { (menutup, } \\
\text { menembok) }\end{array}$ & Workshop kering & $\begin{array}{l}\text { Rutin, (setiap hari kerja. Jam kerja } \\
\text { pagi hingga sore) } \\
\text { Periodik (beberapa hari sekali, jam } \\
\text { kerja pegi hingga sore) }\end{array}$ \\
\hline 3. & $\begin{array}{l}\text { Pewarnaan } \\
\text { kering } \\
\text { (menyolet) }\end{array}$ & Workshop kering & $\begin{array}{l}\text { Rutin, } \\
\text { Periodik }\end{array}$ \\
\hline 4. & $\begin{array}{l}\text { Pewarnaan } \\
\text { basah } \\
\text { (pencelupan } \\
\text { warna), } \\
\text { pelorotan }\end{array}$ & Workshop basah & Rutin, periodik \\
\hline 5. & $\begin{array}{l}\text { Pengeringan } \\
\text { dengan dijemur }\end{array}$ & Ruang jemur & $\begin{array}{l}\text { Rutin, periodik, (panjang waktu } \\
\text { bebas sampai batik kering) }\end{array}$ \\
\hline 6. & $\begin{array}{l}\text { Pengeringan } \\
\text { dengan } \\
\text { dianginkan }\end{array}$ & $\begin{array}{l}\text { Workshop kering, } \\
\text { ruang jemur, ruang } \\
\text { campuran teras, } \\
\text { halaman, pinggir } \\
\text { jalan }\end{array}$ & $\begin{array}{l}\text { Rutin, periodik, (panjang waktu } \\
\text { bebas sampai batik kering) }\end{array}$ \\
\hline 7. & $\begin{array}{l}\text { Penyimpanan } \\
\text { bahan }\end{array}$ & $\begin{array}{l}\text { Workshop, gudang, } \\
\text { ruang campuran }\end{array}$ & Bebas, waktu pendek \\
\hline 8. & $\begin{array}{l}\text { Finishing } \\
\text { (pelipatan, } \\
\text { pemasangan } \\
\text { label merk) }\end{array}$ & $\begin{array}{l}\text { Ruang campuran } \\
\text { depan, toko, } \\
\text { workshop }\end{array}$ & $\begin{array}{l}\text { Bebas (setelah batik jadi), } \\
\text { Periodik, waktu relatif pendek }\end{array}$ \\
\hline
\end{tabular}




\begin{tabular}{|c|c|c|c|}
\hline 9. & $\begin{array}{l}\text { Penyimpanan } \\
\text { batik jadi/ } \\
\text { setengah jadi, } \\
\text { display, } \\
\text { penjualan }\end{array}$ & $\begin{array}{l}\text { Ruang campuran } \\
\text { depan, showroom, } \\
\text { toko }\end{array}$ & $\begin{array}{l}\text { Bebas (setelah batik melalui proses } \\
\text { sebelumnya),Periodik, waktu relatif } \\
\text { pendek }\end{array}$ \\
\hline 10. & Penjualan & Toko & $\begin{array}{l}\text { Rutin, setiap hari, pagi, tutup saat } \\
\text { istirahat siang, sore, malam }\end{array}$ \\
\hline
\end{tabular}

Tabel 5. Aktivitas usaha pengrajin, sifat ruang dan sifat penggunaan ruang

\begin{tabular}{|c|c|c|c|}
\hline & Aktivitas Usaha & Sifat Ruang & Sifat Penggunaan Ruang \\
\hline 1. & $\begin{array}{l}\text { Persiapan kain } \\
\text { mori }\end{array}$ & Relatif bersih, kering & Permanen/ tetap \\
\hline 2. & $\begin{array}{l}\text { Pembatikan } \\
\text { (menutup, } \\
\text { menembok) }\end{array}$ & Kering & Permanen/ tetap \\
\hline 3. & $\begin{array}{l}\text { Pewarnaan } \\
\text { kering } \\
\text { (menyolet) }\end{array}$ & Kering & Permanen/ tetap \\
\hline 4. & $\begin{array}{l}\text { Pewarnaan } \\
\text { basah } \\
\text { (pencelupan } \\
\text { warna), } \\
\text { pelorotan }\end{array}$ & Basah & Permanen/ tetap \\
\hline 5. & $\begin{array}{l}\text { Pengeringan } \\
\text { dengan dijemur }\end{array}$ & $\begin{array}{l}\text { Di ruang terbuka } \\
\text { (luar ruang), } \\
\text { berhubungan dengan } \\
\text { udara luar, relatif } \\
\text { terpapar sinar } \\
\text { matahari }\end{array}$ & Permanen/ tetap \\
\hline 6. & $\begin{array}{l}\text { Pengeringan } \\
\text { dengan } \\
\text { dianginkan }\end{array}$ & $\begin{array}{l}\text { Kering, boleh di } \\
\text { dalam ruangan } \\
\text { dengan sirkulasi } \\
\text { udara yang cukup }\end{array}$ & Permanen/ tetap \\
\hline 7. & $\begin{array}{l}\text { Penyimpanan } \\
\text { bahan }\end{array}$ & Kering & Permanen/ tetap \\
\hline 8. & $\begin{array}{l}\text { Finishing } \\
\text { (pelipatan, } \\
\text { pemasangan } \\
\text { label merk) }\end{array}$ & Relatif bersih, kering & Permanen/ tetap \\
\hline 9. & $\begin{array}{l}\text { Penyimpanan } \\
\text { batik jadi/ } \\
\text { setengah jadi, } \\
\text { display, } \\
\text { penjualan }\end{array}$ & Relatif bersih, kering & Permanen/ tetap \\
\hline 10. & Penjualan & Relatif bersih, kering & Permanen/ tetap \\
\hline
\end{tabular}

Ruang yang digunakan dibedakan sifat ruangnya menjadi relatif bersih dan kering, kering dan basah. Sifat ruang merupakan kondisi ruang yang biasanya terjadi/ 
dibutuhkan dalam melakukan aktivitas usaha batik dan ditentukan oleh sifat kegiatan yang dilakukan yaitu dilakukan dalam kondisi kering, basah, panas, berangin atau bersih (Tabel 5) .

Dengan mengacu pada Septanti (2000) yang menyebutkan bahwa ruang yang digunakan untuk kegiatan usaha dapat bersifaat permanen maupun non permanen. Penggunaan ruang yang permanen apabila ruang tersebut terus digunakan untuk usaha atau khusus digunakan untuk usaha sedangkan penggunaan non permanen adalah apabila ruang digunakan pada saat tertentu saja (banyak pesanan) sehingga terjadi luberan dan pergeseran aktivitas. Dalam Tabel 4 dan Tabel 5 dapat dianalisa bahwa sifat penggunaan ruang untuk setiap kegiatan usaha batik yang dilakukan pengrajin batik di Kampung Batik Jetis ini adalah permanen/ tetap karena :

- Ruang tersebut digunakan secara tetap/ pasti oleh suatu kegiatan usaha (secara tetap menggunakan ruang yang sama untuk suatu kegiatan usahanya)

- Kegiatan usaha tidak meluber menggunakan ruang lainnya dan ruang bukan merupakan hasil luberan aktivitas usaha dari ruang lainnya.

- Ruang digunakan untuk kegiatan yang sama secara tetap, rutin dan kontinyu maupun secara periodik, terputus tetapi berulang/ berlanjut.

\subsection{Letak dan proporsi ruang usaha terhadap rumah tinggal}

Berdasarkan Silas (1993) dalam Swanendri (2000) terdapat tiga tipe dalam hal letak dan proporsi ruang yang dipakai untuk tempat tinggal dan usaha pada suatu UBR, yaitu :

- Tipe Campuran: fungsi rumah sebagai tempat tinggal bercampur dengan ruang kerja. Ruang kerja bersifat fleksibel dan dinamis. Bertempat tinggal masih menjadi fungsi yang dominan.

- Tipe Berimbang: rumah sangat dipisahkan dengan tempat kerja pada bangunan yang sama. Tempat tinggal dan ruang usaha/ kerja memiliki sifat kepentingan yang sama, akses ke tempat kerja terkadang dipertegas dan dipisahkan.

- Tipe Terpisah: pada tipe ini tempat usaha/kerja mendominasi sebagian besar dari total ruangan. Kadang tempat tinggal diletakkan di bagian belakang atau depan tempat kerja yang digabungkan dengan kegiatan kerja. Kadang pemilik usaha tinggal pada tempat lain terpisah dari ruang usahanya.

Berikut adalah analisa tentang letak dan proporsi ruang usaha pada salah satu pengrajin batik tulis di Kampung Batik Jetis yaitu Batik Amri.

\section{Batik Amri}

Tipe Campuran (Gambar 2 dan Gambar 3): diperlihatkan oleh fungsi ruang untuk persiapan kain, display dan penjualan yang bercampur dengan fungsi rumah tangga (ruang tamu) dalam ruang campuran depan (4). Ruang campuran belakang adalah area service (dapur) yang juga digunakan untuk menyimpan bahan mentah, peralatan yang tidak terpakai dan meletakkan bahan setengah jadi sementara $(1,2,3)$. Penggunaan ruang secara bersama ini menunjukkan adanya sebagian fungsi rumah yang menjadi satu dengan ruang usaha, namun hanya sebagian dari ruang usaha saja, bukan keseluruhan. 


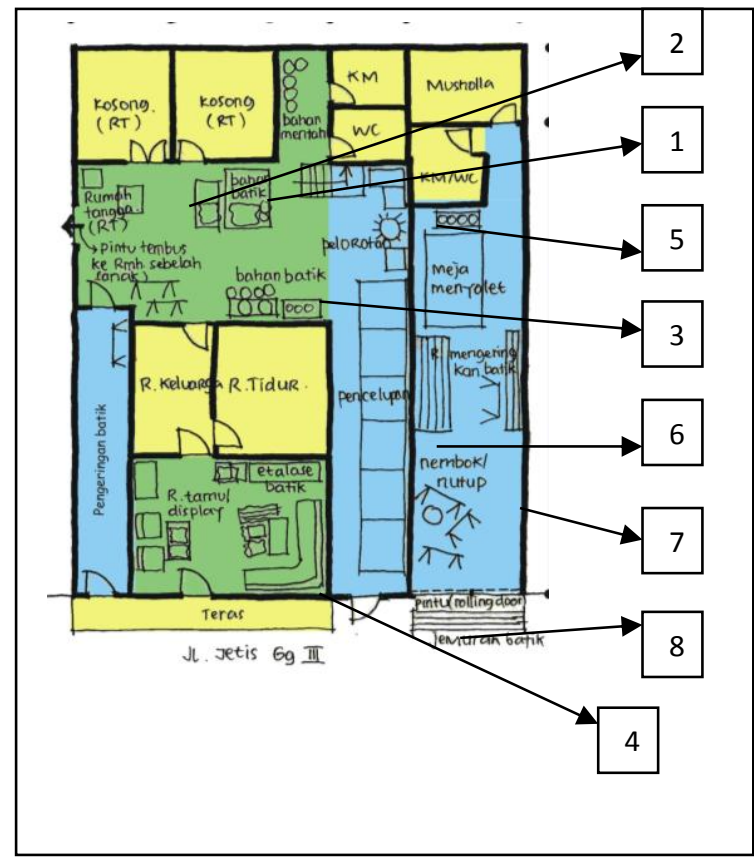

Ruang Usaha

Ruang Rumah tangga

Ruang Campuran

(Usaha+Rumah Tangga)

Gambar 2. Layout rumah dan ruang usaha Batik Amri

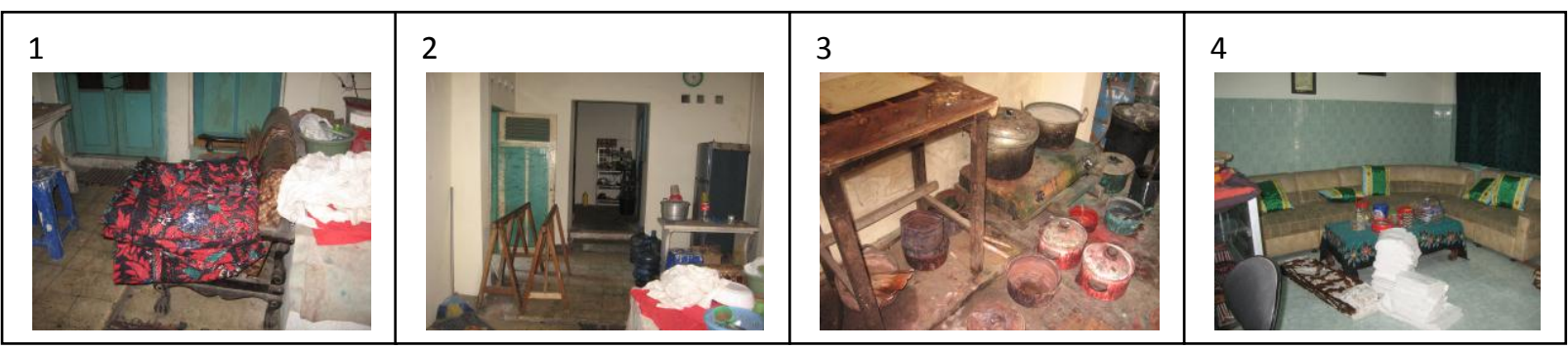

Gambar 3. Ruang usaha Batik Amri yang menunjukkan tipe campuran

Tipe Berimbang (Gambar 2 dan Gambar 4): sebagian dari ruang usaha yaitu workshop basah dan kering berada pada bagian samping rumah. Workshop basah berada dalam bangunan yang sama tetapi dengan batas yang jelas berupa tembok dan pemisahan area dengan area servis di bagian belakang rumah. Workshop basah memiliki akses tersendiri dari bagian samping rumah, meski penghuni rumah juga tetap bisa mengaksesnya dari area dalam rumah $(5,6)$

Workshop kering berada pada bangunan di samping rumah, namun masih dalam batas teritori rumah (7). Akses ke ruang ini hanya melalui pintu depan, sehingga aksesnya tegas dan dipisahkan dari akses rumah tangga (8).

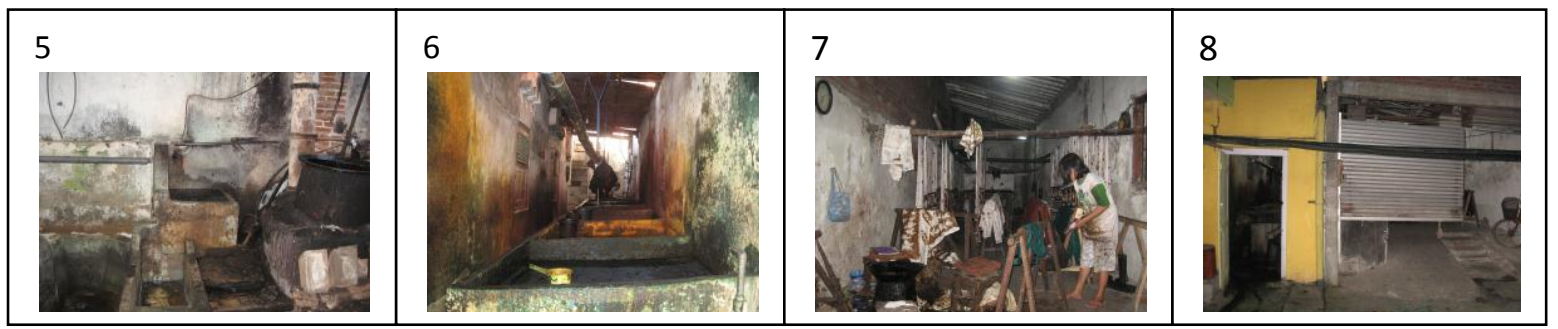

Tipe Terpisah (Gambar 5): Batik Amri memiliki toko di Jl. Pasar Jetis (10) pada kawasan Kampung Batik Jetis. Letak toko terpisah dari rumah tinggal Siti Maryam dan 
workshop (9) yang berada di Jl. Jetis Gg III. Fungsi usaha pada toko ini jelas mendominasi sehingga ruang usaha ini dapat dikategorikan dalam tipe terpisah .
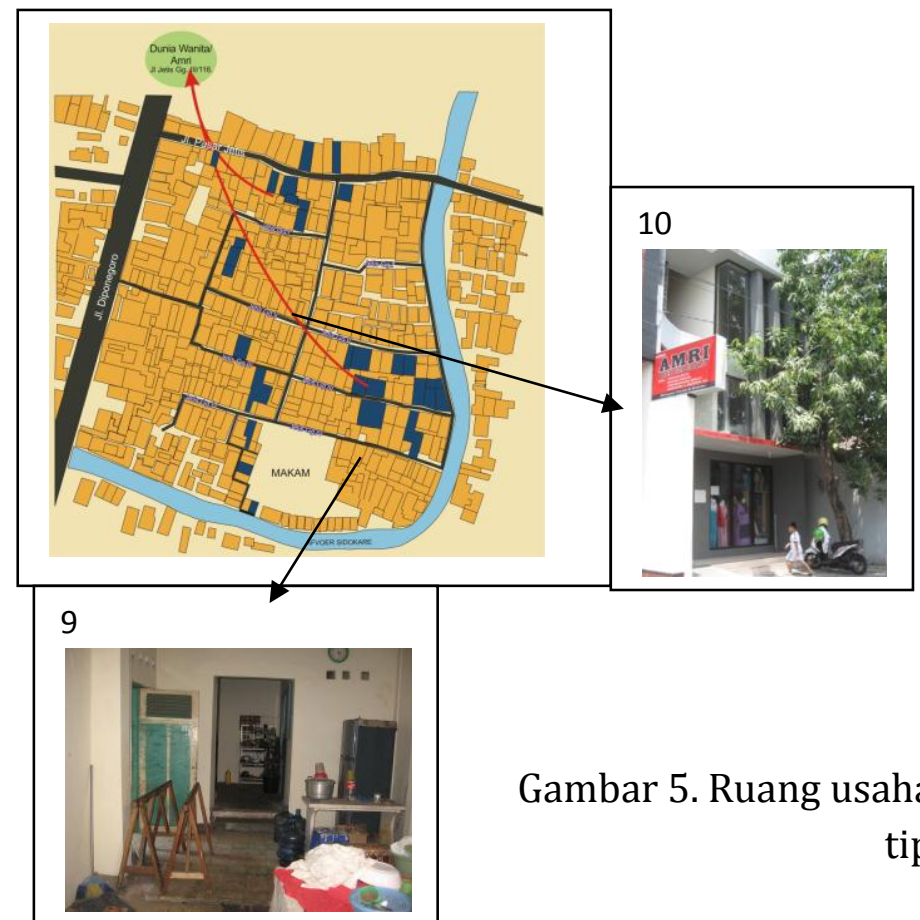

Gambar 5. Ruang usaha Batik Amri yang menunjukkan tipe terpisah.

Dari hasil analisa letak dan proporsi ruang usaha pada setiap pengrajin batik di Kampung Batik Jetis maka didapatkan hasil yang ditunjukkan dalam Tabel 4 berikut.

Tabel 4. Kategori tipe ruang usaha pengrajin batik tulis di Kampung Jetis

\begin{tabular}{|c|c|c|c|}
\hline \multirow{2}{*}{ Pengrajin } & \multicolumn{3}{|c|}{ Kategori Tipe Ruang usaha } \\
\hline & Tipe Campuran & Tipe Berimbang & Tipe Terpisah \\
\hline 1. Batik Amri & $\sqrt{ }$ & $\sqrt{ }$ & $\sqrt{ }$ \\
\hline 2. Batik Yassaroh & $\sqrt{ }$ & & $\sqrt{ }$ \\
\hline 3. Batik Azizah & $\sqrt{ }$ & $\sqrt{ }$ & \\
\hline 4. Batik Amri Jaya & & $\sqrt{ }$ & $\sqrt{ }$ \\
\hline 5. Batik Rahmat & $\sqrt{ }$ & $\sqrt{ }$ & \\
\hline 6. Batik Amali CH & $\sqrt{ }$ & $\sqrt{ }$ & \\
\hline 7. Batik Amali S & $\sqrt{ }$ & $\sqrt{ }$ & \\
\hline 8. Batik HI & $\sqrt{ }$ & $\sqrt{ }$ & \\
\hline 9. Batik Adam & $\sqrt{ }$ & $\sqrt{ }$ & \\
\hline 10. Batik Murni dan Artis & $\sqrt{ }$ & $\sqrt{ }$ & $\sqrt{ }$ \\
\hline 11. Batik Namiroh & $\sqrt{ }$ & $\sqrt{ }$ & $\sqrt{ }$ \\
\hline 12. Batik Daun & $\sqrt{ }$ & & $\sqrt{ }$ \\
\hline 13. Batik Ibrahim Salam & $\sqrt{ }$ & & $\sqrt{ }$ \\
\hline 14. Batik Kamsatun & $\sqrt{ }$ & $\sqrt{ }$ & \\
\hline 15. Batik Dahlia & $\sqrt{ }$ & $\sqrt{ }$ & \\
\hline
\end{tabular}

Dengan analisa yang sama terhadap ruang usaha pengrajin lainnya maka diketahui bahwa tipe ruang usaha pengrajin batik pada umumnya adalah kombinasi dari beberapa/ seluruh tipe dan tidak ada yang hanya merujuk pada salah satu tipe saja 
karena ruang yang digunakan untuk usaha batik cukup banyak sesuai proses batik yang harus dilakukan. Sebanyak 3 pengrajin memiliki kombinasi tipe campuran, berimbang, terpisah. Kombinasi tipe campuran dan berimbang sebanyak 8 pengrajin. Kombinasi tipe campuran dan terpisah sebanyak 3 pengrajin dan kombinasi tipe berimbang dan terpisah sebanyak 1 pengrajin.

\section{Kesimpulan} berikut:

Dari hasil dan pembahasan dalam penelitian maka dapat disimpulkan sebagai

- Aktivitas usaha batik yang dilakukan oleh pengrajin batik tulis terdiri dari aktivitas produksi batik dan pasca produksi batik.

- Ruang yang digunakan untuk aktivitas usaha batik terdiri dari ruang proses produksi (workshop basah, workshop kering, ruang pengeringan, ruang penjemuran,) dan ruang pasca produksi (ruang campuran, ruang display/ showroom, toko)

- Di Kampung Jetis ini terdapat dua macam ruang usaha batik, yaitu yang lengkap dengan showroom/ ruang display dan yang hanya workshop tanpa ruang display

- Hubungan kekerabatan dapat memberikan pengaruh pada penggunaan ruang yaitu adanya pengrajin yang meminjam workshop milik pengrajin lain yang merupakan saudaranya.

- Sifat penggunan ruang usaha pengrajin batik di Kampung Batik Jetis adalah permanen/ tetap karena ruang-ruang usaha tersebut digunakan untuk kegiatan usaha batik secara tetap, pasti, berlanjut secara kontinyu/ rutin (untuk aktivitas yang dilakukan setiap hari) maupun berulang secara periodik/ teratur (untuk aktivitas yang dilakukan setiap beberapa hari sekali)

- Tipe ruang usaha berdasarkan letak dan proporsi ruang usaha pengrajin batik di Kampung Batik Jetis adalah kombinasi dari tipe campuran, tipe berimbang dan tipe terpisah dengan letak ruang usaha yang berada dibelakang, disamping maupun terpisah dari rumah tinggal.

\section{Daftar Pustaka}

Maninggar, Nimas. 2010. Pola Penataan Ruang Rumah Produktif Pengrajin Tenun Ikat Tradisional Desa Parengan Kabupaten Lamongan

Septanti, Dewi. 2000. Rumah sebagai Tempat Tinggal dan Tempat Bekerja: Pola Pemanfaatan Ruang pada Usaha Rumah Tangga (Studi Kasus di Banyu Urip Surabaya)

Silas, Johan. 2000. Rumah Produktif dalam Dimensi Tradisional dan Pemberdayaan. Laboratorium Perumahan dan Permukiman Jurusan Arsitektur FTSP ITS. 